Ssciendo Studia Anglica Posnaniensia 56s1 (2021): 387-409

doi: 10.2478/stap-2021-0010

WORD-INITIAL PREVOCALIC [H-] IN MIDDLE ENGLISH

\author{
JERZY WELNA ${ }^{1}$
}

\begin{abstract}
The present contribution discusses the phonological reality of initial fricative $h$ - in words of Germanic and French origin in dialectally identified 106 texts from the Innsbruck Corpus of Middle English Prose (Markus 2008), with the focus on native words where initial $h$ - is frequently mute, as confirmed by (a) $h$-less spellings like ouse for house or especially (b) the use of the article an before $h$-nouns. In the early texts a phrase like an house may testify to the survival of the historical determiner ( $\mathrm{OE} \bar{a} n)$ put before both initial vowels and consonants, but in later texts this position may indicate mute initial $h$ - in the following noun (or in an adjective before a noun). The paper offers numerical data concerning such distributions in particular Corpus texts as well as analogous data referring to the adjectives MIN and THIN (later on $m y$ and thy), where the final nasal consonant was lost when used in the function of an attribute. Consequently, this development led to the rise of a set of possessive adjectives with a syntactic, not phonological, distribution The data from the Innsbruck Corpus seem to indicate that an early loss of initial prevocalic $h$-in Middle English words of Germanic origin took place in particular texts rather than in texts from the whole region. The evidence from the Corpus shows that the implementation of the contemporary distribution, i.e., $a$ before consonants and an before vowels, had a partly regional character, its first traces coming from as early as the $13^{\text {th }}$ century.
\end{abstract}

Keywords: Article; dialects; French; initial $h$-; spelling; Middle English.

\title{
1. Introductory remarks
}

The question of the phonological status of word-initial prevocalic $h$ - emerges in practically every study of English historical phonology. Their authors almost unanimously agree that in words of French and Latin origin, like honour, houre, host, the sound corresponding to initial prevocalic $h$ - was not articulated, with the exception of words such as hardy, haste, heron, etc., which had crept into French from Old Germanic and later became fully integrated in Middle English

$1 \quad$ University of Warsaw, jawelna@uw.edu.pl 
(cf. Brunner 1963: 42-43, Jordan 1974 [1925]: 228). This means that language users who articulated initial prevocalic $h$-in native words like house, harm or hot, treated also loanwords like hardy, hasty as native.

Writing about the grapheme $h$-, Scragg (1970) states that in the initial position before a vowel $<\mathrm{h}>$ "has been unstable throughout the history of written English", which is also proved by "instances of the non-etymological absence or presence of initial $h$ in native words" (see his list of non-etymological spellings with initial $h$-). In loanwords from French, $h$ in this position was mute (cf. istorie for historie) and was also silent in native words with a weak stress, e.g., (h)is, (h)em etc. (cf. Fisiak 1968: 61). But in his later work, a monograph on the history of English spelling, Scragg (1974) concentrated only on (non-)etymological $h$ - in loanwords from French and Latin, neglecting the issue of the phonetic reality of the grapheme $h$ - in words of Germanic, chiefly English, origin.

It is evident that the only certain indication of mute initial prevocalic $h$ - are spellings with the corresponding grapheme deleted, such as the occasional forms elf for half or ard for hard in Ormulum. The situation becomes more complex when etymologically correct $h$ - is written in the word-initial position because in such cases speakers of Middle English either pronounced the fricative or dropped it. In native words, Scandinavian, and perhaps French words of Germanic origin, like hardy, haste etc. mentioned earlier, speakers tended to retain the fricative sound, while in words of purely French or Latin origin initial $h$ - was deleted, as it was in Vulgar Latin and French. Consequently, French loanwords were probably articulated in English without this initial sound, although forms with etymological $h$ - spelling inserted were not rare and grew in number with the passing time, especially during the Renaissance period.

Concerning the pronunciation of initial $h$ - in words with a Germanic background phonologists vary in their opinions. The most characteristic seems Wright \& Wright's (1928: 129-130) statement, who suggest a solution as simple as possible:

(1) OE. initial $\mathbf{h}[\ldots]$ was an aspirate like the $\mathbf{h}$ in NE. hand, but with a strong emission of breath between the $\mathbf{h}$ and the following vowel or consonant.... OE. initial $\mathbf{h}$ remained in ME. before accented vowels, as hous (OE. hūs), hẹ̆len (OE. hǣlan) to heal [...]. But before unaccented vowels it often disappeared, especially in pronominal forms, as $\mathbf{e m}, \mathbf{i m}$, it beside accented hem them, him, hit [... ]. AN. initial $\mathbf{h}$ was not pronounced, and accordingly it was often omitted in the writing of such loan-words as habit abit, haste aste, heire eire heir $[\ldots]$.

An analogous status of initial $h$ - is also suggested in Brunner (1963: 42-43), who, however, claims that in "French words of Gmc origin" initial $h$ - was articulated 
in Middle English. A similar stand is taken by Ekwall (1975: 79-80) with reference to the turn of the Early New English period.

Writing about non-etymological h- in spellings, like

(2) hoke (oak), hought (out), hende (end), hevelle (evil), hangyr (anger), howlde (old) in Norfolk Guilds (1387), St. Editha (1420), Bokenam and Cely Papers

and other late $14^{\text {th }}-15^{\text {th }}$ century sources, Wyld (1936: 219-220), rejected the view that such forms reflected standard pronunciation. In his opinion, "the habit of 'putting an h' was widespread as a vulgarism before the later eighteenth century". But more recently, Milroy (1983, 1992a: 197-201) launched an even bolder hypothesis of the very early phenomenon of $h$-dropping which was reflected in the instability of $h$-forms especially in the East Midland (which is supported by the data from LALME). According to Milroy (1992a: 200), "in the absence of strong orthographic standardization, the scribes would omit it [i.e., $h$-; JW] on some occasions and insert it 'hypercorrectly' on others". Milroy's hypothesis was in agreement with Charles Jones's account of $h$-dropping and insertion (Jones 1989: 265-274; cf. his list of examples illustrating initial $h$ - variability in Layamon's Brut).

As regards the stability of initial $h$ in the earliest documents, Hogg states that initial $h$-was lost as early as Old English. His examples include ondweorc (handiwork), yldo for hyldo 'kindness' or reverse healle for ealle 'all', etc.

(3) Initially [h] usually remained but throughout there are occasional examples of the failure of initial [h] to be represented in spelling. [...] loss or unhistorical use of $\langle\mathrm{h}\rangle$ initially is particularly frequent in the poems of the Exeter Book, CP(H), and Li [...] (Hogg 1992: 273)

A much more detailed account of non-etymological $h$ in words of Old English origin can be found in Minkova (2003: 160-165). Her list of examples selected from Old English poetic and prose texts based on Scragg (1970) shows a proportion of roughly $70 \%$ of initial $h$-insertions to around $30 \%$ of initial $h$ deletions, where inserted $h$ s could have represented the glottal stop. Elsewhere, Minkova (2014: 104) postulates the status of "an obstruent phoneme" for OE $h$ and defends the consonantal status of initial prevocalic $h$ - in Middle English, simultaneously emphasising its unstable character.

The two classic historical phonologies, those by Luick and Jordan, also devote some space to the problem of $h$-instability. Luick (1940: 1092) described the regional conditioning of the change in the period from the $15^{\text {th }}$ century onwards as follows: 
(4) In einer Periode, die mit dem 15. Jahrhundert, in einigen Gegenden vielleicht etwas früher, einsetzt, schwand das anlautende $h$ in Fällen wie hand, house, hell in erheblichem Umfange auf dem größten Teil des Sprachgebietes: nur Schottland, Irland, Nordhumberland und Teile von Cumberland und Durham bewahren es. Auf dem ganzen übrigen Gebiet ist nach dem Ausweis der lebenden Mundarten von dem Wandel ergriffen worden.

[In the $15^{\text {th }}$ century, but earlier in certain areas, initial [h] was lost in words like hand, house, hell to a considerable extent on a major part of the territory where English was spoken. That sound was retained only in Scotland, Ireland, Northumberland, parts of Cumberland and Durham. Elsewhere the change was effected, as is evidenced by the living dialects [translation mine; JW].

Luick's attempt at determining both temporal and regional conditioning of the change (here: loss of initial prevocalic $h$ - in native words) placed the process in the $15^{\text {th }}$ century on the major territory of England, to the exclusion of the northern areas. But in his grammar Luick said almost nothing about the status of initial $h$ in Early Middle English. With reference to Late Middle English he emphasized the instability of initial $h$-spellings, disregarding social influences which may have been at work.

In Jordan's version unstable $h$ - was due to either French influences or phonetic reasons, as some scribes apparently considered $h$ - as aspiration rather than a regular consonant:

(5) In initial position before a vowel $h$ was aspirate as in $\mathrm{OE}$ and still became sounded as such in native pronunciation in accented syllables, although also often weak (habben, hōnd etc.) [...]. Severe alternations of the $h$ writing in accented syllables rest in general upon French influence [...]. Early omission of the $h$ (already in OE) could also rest on the fact that the writer did not consider the aspiration as a full valued sound. [Chaucer consistently uses an, myn, thyn before $h$ words which indicates he did not pronounce the $h \ldots]$. Jordan (1974 [1925]: 178-179)

In the quotation above the fragment in square brackets referring to Chaucer's usage is an important amendment to the original text made by its editor E. J. Crook. The fragment refers to the use of the article an and the adjectives myn, thyn directly before words with initial $h$ - to indicate that the initial fricative is not articulated. This logical statement concerning the use of simple spelling methods to suggest how a word should be pronounced has given the present author an idea to conduct a closer investigation of the distribution in Middle English prose texts of the forms of these three words before nouns and adjectives beginning with $h$ - 


\section{2. $\mathrm{A}(\mathrm{N}), \mathrm{MI}(\mathrm{N})$ and $\mathrm{THI}(\mathrm{N})$}

Before presenting the results of the study we will try to establish the grammatical status of the indefinite article an and its distribution. In the grammars of Old English an is treated not as an article but as a numeral representing 'one'. In that meaning it could stand before nouns in the singular irrespective of the initial sound of the following word, i.e., its position was determined morphologically. Its later fates lack a precise description. Apart from Süsskand's (1935) early study embracing only Old and Early Middle English, where an is treated as the surviving form of $\mathrm{OE} \bar{a} n$, the question when precisely an obtained its contemporary grammatical status and its present-day phonology-based distribution remains debatable. Scant information in (a) Ekwall (1975) and (b) Fischer \& van der Wurff (2006) leaves the issue of the chronology of the change open; cf.:

(6) (a).The indefinite article (originally identical with the numeral one) had the forms $a$, an in the late ME period, but distribution according to the initial sound of the following word had not yet been fully established. In EModE, as today, $a$ was used before a consonant, an before a vowel, but also frequently before [h] (as in an hand, an hundred) (Ekwall 1975: 95).

(b) In ME, indicative presentative an [...] becomes truly separate from the numeral an, in that a formal distinction develops between the two. The OE numeral $\bar{a} n$ develops regularly into ME oon, while the vowel in the article is reduced to short [a], and the word loses the final nasal when the next word begins with a consonant. (Fischer \& van der Wurff 2006: 117).

These and several other sources (for more details see especially Lutz 1991: 5967, section "achte Stufe", and Sommerer's recent study of 2018) allow one to formulate the following statements concerning the formation of the indefinite article with the contemporary distribution before vowels and consonants:

(a) In Middle English, the unaccented form of the Old English numeral $\bar{a} n$ showed a tendency towards becoming the indefinite article.

(b) In the accounts of most historical linguists the rise of the indefinite article on the whole territory of England is dated to the $15^{\text {th }}$ century or even later

(c) With the lapse of time, Middle English shows more traces of the phonetic adjustments of the "numeral/article" to the initial sound in the directly following noun or adjective. Consequently the Middle English data should be split into at least two periods: the one until c. 1400 and and the other after that date. 
The data collected in the present study may help establish the principles of the distribution of the forms of an/a and those of the possessive adjectives $\mathrm{mi} / \mathrm{min}$, thi/thin etc. in the working corpus consisting of the forms of these three words followed by nouns or adjectives with initial $h$ - This working corpus is based upon 106 texts from the Innsbruck Corpus of Middle English Prose (Markus 2008; see the Appendix), excluding texts with uncertain localization and those supplying no examples of the contexts under investigation. Of course, a study based on the original manuscripts would have brought more precise results, nevertheless the data from this major corpus of Middle English prose texts may be treated as a tool helping to discover rudimentary standard patterns in the distribution of the numerals/articles and possessive adjectives.

To simplify data presentation, the items are symbolized here by the following six lemmas:

(7) $\mathrm{AN}($ an $)$

MIN (min, myn)

THIN (thin, thyn, pin, pyn)
$\mathrm{A}(a)$

$\mathrm{MI}(m i, m y)$

THI (thi, thy, pi, py) ([no forms with $\delta$-])

Because of lack of certainty as regards the pronunciation of final $-e$ in mine, thine, etc. in prose texts, where final $-e$ can be articulated or not, such forms had to be excluded. As regards the potential readings of, e.g., the noun house ( $\mathrm{OE} h \bar{u} s)$ in Middle English after $a / n$, the following pronunciations were theoretically possible:

(8) (a) an hous(e)

(b) an ous(e)

[a'nu:s] or [an 'hu:s]

(c) a house

[a'nu:s]

[a 'hu:s] or [a 'u:s]??

Of the four (or five?) pronunciations it is only the hiatus form in parentheses, i.e., (8c) [a 'u:s], which could hardly be accepted as a natural sequence, while the other form in (c), i.e., [a 'hu:s], is a pronunciation fully compatible with that employed in Modern English, i.e.. [ə'haus]. The form (8b) is self-explicit as one cannot expect here a reading other than [a'nu:s]. The most problematic is the ambiguous context (8a) typical of Early Middle English, where [an 'hu:s], with an functioning as an article or a numeral, was a continuation of the original Old English form $\bar{a} n$. In later Middle English when the phonological distribution of the indefinite article became established, the sequence an house [a'nu:s] or [an'hu:s] was replaced by a house with one possible reading, i.e., [a'hu:s], with a subsequent diphthongisation of [u:].

In the following sections the materials classified according to dialects are split into those from before and after 1400 . Our focus is on the numeral/article, while the possessive adjective data are to be treated as supplementary. 
With reference to the forms of $a(n)$ in the Innsbruck Corpus texts, the symbols (an, AN, a, A) put under the label TYPE in the items (10-16) below should be understood, as follows:

(9) Before words with initial prevocalic $h$-:

an an is used 1-4 times (rare)

AN $a n$ is used 5 times or more (frequent)

a $\quad a$ is used $1-4$ times (rare)

A $\quad a$ is used 5 times or more (frequent)

The above symbols can be combined when in a text both $a$ and $a$ stand before initial prevocalic $h^{-}$, thus AN/a, AN/A, an/A, an/a.

Parentheses enclose numbers of words of French or Latin origin, e.g., (2F) reads "the form is found before two loanwords from French". This seems important as the loss of word-initial prevocalic $h$-was natural in words of French origin. Texts are arranged chronologically, starting from the oldest ones. As said earlier, the data concerning the possessives $\mathrm{mi} / \mathrm{n}$, thi/n are here treated as supplementary.

\section{South (Western) and Kentish (A/N, MI/N, THI/N before prevocalic $h-)$}

The distribution of the above words before prevocalic $h$ - in the southerly dialects (South West and Kentish) is as follows (the two border date texts are treated as belonging to the $14^{\text {th }}$ century). For full information concerning particular texts, see the Appendix.

(10) SOUTH (WEST) (8 texts) MS date an MIN/THIN a MI/THI TYPE

\author{
Hali Meidenhad (Bod.) \\ Hali Meidenhad (BL Titus) \\ Twelfth-Cent. Homilies (Bod.) \\ History of the Holy Rood-tree \\ Old English Homilies \\ Trevisa, Methodius \\ Trevisa, Dialogus
}

A Myrour to Lewde Men...

(11) KENTISH (1 text)

Twelfth-Cent. Homilies (Vesp.)

$\begin{array}{cccccc}(1150+) & 1 & 1 & - & - & \text { an } \\ (1150+) & 2 & 13 & 1 & - & \text { an/a } \\ (1150+) & 1 & 1 & - & - & \text { an } \\ (1150+) & 1 & - & - & - & \text { an } \\ (\mathrm{a} 1225) & 2 & 2 & - & - & \text { an } \\ (1359+) & 3 & - & - & - & \text { an } \\ (\mathrm{a} 1402) & - & 2(2 \mathrm{~F}) & - & - & \text { (an) } \\ (\mathrm{c} 1400) & 53(6 \mathrm{~F}) & 10 & - & - & \text { AN }\end{array}$

MS date an MIN/THIN a MI/THI TYPE

$\begin{array}{lllllll}(1250+) & 3 & 9 & - & - & & \text { an }\end{array}$


In the Innsbruck Corpus the earliest prose works come from the South (West). The evidence of $\mathrm{A}(\mathrm{N}), \mathrm{MI}(\mathrm{N}), \mathrm{THI}(\mathrm{N})$ before $h$-words is very scant in both Early and later Middle English. The few examples of an confirm their status as numerals, although a single form of $a$ (a heate 'heat') found in Hali Meidenhad (Titus; 63/665), an early text, may confirm the phonetic reality of the fricative in heate. The use of adjectives with final $-n$ has nothing to do with phonological distribution because $n$-less forms are not found even in texts from the later period. Curiously, of the 13 instances of MIN/THIN in Hali Meidenhad (Titus), as many as 10 stand before the noun he(o)rte 'heart'. The 53 instances of an retained before $h$ - in A Myrour to Lewde Men and Wymmen, a late text with around 1000 occurrences of $a$ before consonants different from $h$, may be a strong indication that initial $h$-after an was not articulated. Kentish $12^{\text {th }}$ Century Homilies offers a very small number of forms, while the other Kentish text (Sermons, Oxford Laud MS. 471) contains no relevant data.

\section{West Midland (A/N, MI/N, THI/N before prevocalic $h$-)}

The distribution of the above words before prevocalic $h$ - in the West Midland is as follows (the single border date text is treated as belonging to the $14^{\text {th }}$ century). (For a full list of texts see the Appendix):

\section{(12) WEST MIDLAND (15 texts) MS date AN MIN/THIN A MI/THI TYPE}

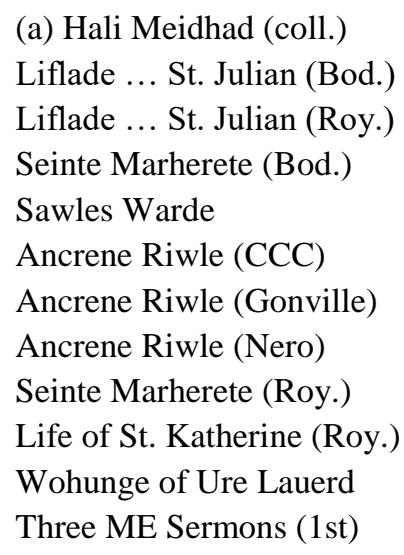

an

$$
\text { an/a }
$$$$
\text { an }
$$$$
\text { an }
$$$$
\text { an }
$$$$
\text { AN }
$$$$
\text { AN }
$$$$
\text { AN }
$$$$
\text { an }
$$$$
\text { AN }
$$$$
\begin{array}{lcllll}
(\mathrm{a} 1300) & 1 & 7 & - & 8 & \text { an } \\
(\mathrm{c} 1400) & 12(2 \mathrm{~F}) & 5 & - & - & \text { AN }
\end{array}
$$

(b)

Saint Nicholas

Saint George
Saint Bartholomew

(c1450)

(c1460) (c1450)

$-\quad-$ an 
The earlier West Midland texts, i.e., those from before 1400 (12a), show more or less the same pattern as texts from the South (see (10) above), i.e., 85 instances of the numeral $a$ before words with initial prevocalic $h$ - are contrasted with a single instance of the article $a$ before $h$ - (cf. a surprising, very early appearance of an $n$-less determiner form a heuene in Liflade ... St. Julian; Bod., 12 c.). A consistent appearance of AN, MIN, THIN before 1400 strongly supports the hypothesis of mute initial prevocalic $h$ - in that region (102 $n$-forms against 10 forms without $n$ of the adjectives). As regards Ancrene Riwle (Nero; c. 1225), an appears there only before vowels (11) and $h$ - (10), while $a$ is found before consonants other than $h$ - (107 occurrences). This means that in Ancrene Riwle (Nero) initial prevocalic $h$ - was certainly not articulated after $a n$. All other early texts (12a) contain the article $a n$ before words with initial vowels and consonants.

The three texts from the $15^{\text {th }}$ century (12b) also show the predominance of the longer forms, the only example of the $n$-less article $a$ before $h$-nouns being the phrase $a$ hole in St. George, Egerton (74/r21). The $15^{\text {th }}$ century data with the prevalence of an over $a$ seem to show the Western area as the territory where initial prevocalic $[\mathrm{h}]$ may have had a tendency not to be articulated.

\section{South/West-East Midland (A/N, MI/N, THI/N before prevocalic $h$-)}

The distribution of the above words before prevocalic $h$ - in a Southern region bordering on the West/East Midland is as shown below (the single border date text is treated as belonging to the $14^{\text {th }}$ century; for a full list of texts see the Appendix):

(13) S/WM/EM (5 texts)

(a) Lollard Sermons

(b) The Art of Hunting

Three Kings of Cologne (Roy.)

Three Kings of Cologne (Cbr.)

Late ME Treatise on Horses

\section{MS date}

AN MIN/THIN A

$$
26(4 \mathrm{~F}) \quad 16
$$

3

$\begin{array}{ll}4 & 8 \\ 2 & - \\ 3(1 \mathrm{~F}) & - \\ 62 & 2\end{array}$

$\begin{array}{lll}1 & 2 & \text { an/a } \\ 12(2 \mathrm{~F}) & - & \text { an/A } \\ 13 & - & \text { an/A } \\ - & 1 & \text { AN }\end{array}$

This small group of texts represent a Southern region bordering on the West and East Midland. In the text from before 1400 (Lollard Sermons), 26 tokens of an are contrasted with only 3 instances of $a$. Surprisingly, this relatively early text shows a practically contemporary distribution, i.e., $a$ before all consonants (except $h$-) and an before all vowels. Its 37 occurrences of an before a vowel (and 26 before $h$-) are confronted with around 700 instances of $a$ before consonants 
(and only 3 instances of $a$ before $h$-). The text supplies contrasting forms, i.e., 4 cases of an hous (e.g., LS 24/454) and 2 cases of a hous(e) (e.g., LS 60/272).

Texts from the latter half of the $15^{\text {th }}$ century (c. 1445-1500) show a characteristic change, namely, before initial $h$ - the article $a$ prevails over an, except in Late Middle English Treatise on Horses (Sloane, Berkshire/S. Oxfordshire) with its 62 occurrences of an. Pairs contrasting at least in their graphic shapes are also found; cf.:

The Art of Hunting: an hert (e.g. 47/r24): a hert (46/r13);

Three Kings of Cologne, Royal 32/r26 an half: 130/r20 a half,

Three Kings Cbr. an houws (65/r29): a hows (e.g. 21/r36).

However, it is difficult to determine whether words containing initial $h$ in such pairs really differed in their pronunciation. Then, the items in the first pair would have developed either a phonological ([an ert: a hert]) or allomorphic contrast (an hert: a hert), with initial $h$ remaining unaffected in the latter.

\section{East Midland (A/N, MI/N, THI/N before prevocalic $h$-)}

The distribution of the above words before prevocalic $h$ - in the East Midland is as follows the single border date text is treated as belonging to the $14^{\text {th }}$ century; for a full list of texts see the Appendix):

\section{(14) EAST MIDLAND (31 texts) MS date AN MIN/THIN A MI/THITYPE}

(a) Peterborough Chronicle

Vices and Virtues

Ancrene Riwle (Pepys)

Ancrene Riwle (Titus)

Mandeville's Travels

Lavynham, A Lytil Tretis

Pepysian Gospel Harmony

$\begin{array}{cccccc}(1070-1154) & 4 & - & - & - & \text { an } \\ (\mathrm{a} 1225) & 6 & 3 & - & - & \mathrm{AN} \\ (\mathrm{c} 1225) & 39 & - & - & 1 & \mathrm{AN} \\ (\mathrm{c} 1225) & 12(1 \mathrm{~F}) & 13 & 2 & 4 & \mathrm{AN} / \mathrm{a} \\ (1350+) & 17 & 2 & 2(1 \mathrm{~F}) & - & \mathrm{AN} / \mathrm{a} \\ (\mathrm{a} 1400) & 9(1 \mathrm{~F}) & 1 & - & - & \mathrm{AN} \\ (\mathrm{c} 1400) & 16 & 1 & - & - & \mathrm{AN}\end{array}$

(b) Lantern of Light

Cloud of Unknowing

(a1415)

$15(3 \mathrm{~F})$

15

$(1400+)$

7

$22(1 \mathrm{~F})$

$(1400+)$

4

2

14

$18 \quad$ an/A

Pater Noster of Richard

(1400+)

7
4

5

AN/a 


\begin{tabular}{|c|c|c|c|c|c|c|}
\hline Ermyte & & & & & & \\
\hline Life of Adam and Eve & $(1400+)$ & 7 & 6 & - & $1(1 \mathrm{~F})$ & AN \\
\hline $\begin{array}{l}\text { Julian of Norwich's } \\
\text { Revelations }\end{array}$ & (c1420) & - & 1 & 6 & 12 & A \\
\hline Paston Letters 2 & $(1420-1500)$ & $10(2 \mathrm{~F})$ & 12 & $2(1 \mathrm{~F})$ & 10 & $\mathrm{AN} / \mathrm{a}$ \\
\hline Paston Letters 3 & $(1420-1500)$ & $12(2 \mathrm{~F})$ & - & 6 & $12(1 \mathrm{~F})$ & $\mathrm{AN} / \mathrm{A}$ \\
\hline Paston Letters 4 & $(1420-1500)$ & $19(2 \mathrm{~F})$ & 21 & 4 & 22 & AN/a \\
\hline Paston Letters 5 & $(1420-1500)$ & $24(4 \mathrm{~F})$ & $20(1 \mathrm{~F})$ & 4 & $16(1 \mathrm{~F})$ & $\mathrm{AN} / \mathrm{a}$ \\
\hline Paston Letters 6 & $(1420-1500)$ & $11(3 \mathrm{~F})$ & - & 8 & 12 & $\mathrm{AN} / \mathrm{A}$ \\
\hline Deonise Hid Diuinite & (a1425) & 1 & 19 & - & 1 & an \\
\hline Misyn, The Fire of Love & $(1435)$ & - & - & 11 & 40 & A \\
\hline $\begin{array}{l}\text { Capgrave, Lives of St. } \\
\text { Augustine }\end{array}$ & $(1440)$ & $14(5 \mathrm{~F})$ & $5(2 F)$ & $24(1 \mathrm{~F})$ & 3 & $\mathrm{AN} / \mathrm{A}$ \\
\hline Metham: Physiognomy & (1448) & $6(1 \mathrm{~F})$ & - & 2 & - & $\mathrm{AN} / \mathrm{a}$ \\
\hline Speculum Christiani & $(\mathrm{c} 1450)$ & 12 & 7 & 3 & 7 & AN/a \\
\hline Macer Floribus & $(1450+)$ & $14(4 \mathrm{~F})$ & 7 & - & - & $\mathrm{AN}$ \\
\hline $\begin{array}{l}\text { Lincoln Diocese } \\
\text { Documents }\end{array}$ & $(1450+)$ & - & $3(2 F)$ & $18(1 \mathrm{~F})$ & $18(3 \mathrm{~F})$ & A \\
\hline $\begin{array}{l}\text { Pecock, Follower to the } \\
\text { Donet }\end{array}$ & (c1453) & $29(6 \mathrm{~F})$ & 9 & - & 1 & $\mathrm{AN}$ \\
\hline $\begin{array}{l}\text { English Register of } \\
\text { Oseney Abbey }\end{array}$ & $(1460)$ & 18 & - & $\begin{array}{c}3 \\
145(116 \mathrm{~F})\end{array}$ & AN/a & \\
\hline $\begin{array}{l}\text { Capgrave, Abbreviation } \\
\text { of Chron. }\end{array}$ & (c1462) & 1 & - & $91(16 \mathrm{~F})$ & - & an/A \\
\hline Cely Letters & $(1472-78)$ & 13 & $7(1 \mathrm{~F})$ & 15 & 23 & $\mathrm{AN} / \mathrm{A}$ \\
\hline Pecock, The Donet & $(\mathrm{c} 1475)$ & $24(9 \mathrm{~F})$ & 8 & - & 1 & $\mathrm{AN}$ \\
\hline $\begin{array}{l}\text { Agnus Castus, A ME } \\
\text { Herbal }\end{array}$ & $(1500+)$ & 241 (F224) & 5 & $1(1 \mathrm{~F})$ & - & $\mathrm{AN} / \mathrm{a}$ \\
\hline
\end{tabular}

The Innsbruck Corpus offers a vast range of texts from the East Midland, especially those from the $15^{\text {th }}$ century. Although an, as was expected, prevails before $h$-in the early compositions (14a), each of the two texts, Ancrene Riwle (Titus, c. 1225) and Mandeville's Travels (1350+), contains two forms of $a$ before $h$-. But it seems that before 1400 the numeral/article continued to be used like in Old English, except in two texts. The first, Ancrene Riwle (Pepys; c. 1225) developed a currently existing distribution, with an used before vowels and initial prevocalic $h$-, and $a$ only before consonants, which means that words with initial $h$ - are treated like those with an initial vowel. The other text, Lavynham's A Lytil Tretis, also shows a regular pattern (with one exception: an leful liking 24/r36). 
In the later period retention of $h$ - due to the preceding article $a$ seems to be a feature of Julian of Norwich's Revelations, Lincoln Diocese Documents and Capgrave, while $h$ - appears to have been deleted in Pepysian Vowel Harmony, Life of Adam and Eve, Macer Floribus, Pecock (both Donets) and perhaps Agnus Castus.

The unstable position of initial $h$ - is best illustrated by spellings in Capgrave's two texts where this letter is non-etymological:

Of Richard Story he took a hooth, for he swore on a book pat he schulde neuyr meynten no swech opiniones. And aftir pis hooth be kyng saide, 'And I swere here onto be, if euyr pou breke pin ooth, pou schal deye a foul deth'. Abbreviation of Chronicles (204/r9-13)

Beati apostoli epistola, where he tellith pat pis Vitalis was an huscher of gramer in Melan... Lives of St. Augustine 30/r6-8.

In both cases inserted $h$ - has no phonological substance; cf. OE $\bar{a} b$ 'oath', AN usser 'usher'. Note also myn howllde lady 'my old lady' (Cely Letters 97/r52), myn hoold lady (Paston Letters vol 5, p. 297) and an hesy servise 'an easy service', p. 123.

\section{London (A/N, MI/N, THI/N before prevocalic $h$-)}

The distribution of the above words before prevocalic $h$-in London is as follows (the border date texts are treated as belonging to the $15^{\text {th }}$ century; for a full list of texts see the Appendix):

(15) LONDON (30 texts) MS date AN MIN/THIN A MI/THI TYPE

$\begin{array}{lllllll}\text { (a) Complaint of Our Lady } & (1350+) & 3 & 1 & - & - & \text { an }\end{array}$

(b) Book of ... St.

Bartholemew

$\begin{array}{llllll}(1400+) & 18(6 \mathrm{~F}) & 3 & 1 & 2 & \text { AN/a }\end{array}$

Chaucer's Treatise on

Astrolabe

$(1400+) \quad 6(1 \mathrm{~F}) \quad 6(1 \mathrm{~F}) \quad-\quad-\quad-\quad$ AN

Chaucer, Melibeus (Hgw)

$\begin{array}{llllll}(\mathrm{c} 1402) & 5(1 \mathrm{~F}) & 10(1 \mathrm{~F}) & - & - & \mathrm{AN}\end{array}$

Chaucer, Person's (Hgw)

(c1405)

$14(6 \mathrm{~F})$

$8(1 \mathrm{~F}) \quad-\quad-\quad \mathrm{AN}$

Chaucer, Person's (Elles)

(c1405)

$12(5 \mathrm{~F}) \quad 11(2 \mathrm{~F}) \quad-\quad-\quad \mathrm{AN}$

Chaucer, Melibeus (Elles)

(1410)

$5(1 \mathrm{~F}) \quad 10(1 \mathrm{~F})$

AN

Chaucer, Boece

(1425+)

$8(2 \mathrm{~F}) \quad 16(3 \mathrm{~F})$

AN/a 


\begin{tabular}{|c|c|c|c|c|c|c|}
\hline English Wks of Wyclif 2 & (a1424) & $22(6 \mathrm{~F})$ & 3 & - & 1 & AN \\
\hline English Wks of Wyclif 1 & (a1425) & $16(3 \mathrm{~F})$ & 3 & - & - & $\mathrm{AN}$ \\
\hline Speculum Sacerdotale & $(\mathrm{c} 1425)$ & $43(12 \mathrm{~F})$ & $7(1 \mathrm{~F})$ & 1 & 12 & $\mathrm{AN} / \mathrm{a}$ \\
\hline Dictionaries and Saying & $(1450)$ & 3 & - & 4 & 9 & an/a \\
\hline Revelations of St Birgitta & $(1450+)$ & $20(5 F)$ & $23(2 \mathrm{~F})$ & $6(1 \mathrm{~F})$ & $18(1 \mathrm{~F})$ & AN/A \\
\hline Caxton, Life of S.Thomas & $(\mathrm{c} 1470)$ & - & - & 1 & - & $\mathrm{a}$ \\
\hline $\begin{array}{l}\text { Caxton, Dialogues in Fr. \& } \\
\text { Eng. }\end{array}$ & $(1483)$ & $10(1 \mathrm{~F})$ & - & $3(1 \mathrm{~F})$ & $4(1 \mathrm{~F})$ & $\mathrm{AN}$ \\
\hline $\begin{array}{l}\text { Caxton, Knight of La Tour } \\
\text { Laundry }\end{array}$ & $(1483)$ & $47(7 F)$ & 7 & 13 & 5 & AN \\
\hline Caxton, Quattuor Sermones & $(\mathrm{c} 1483)$ & 5 & 28 & - & 12 & AN \\
\hline Caxton, The Curial & $(\mathrm{c} 1484)$ & $3(1 \mathrm{~F})$ & 1 & - & 1 & an \\
\hline Caxton, Paris and Viene & $(1485)$ & $13(2 \mathrm{~F})$ & $12(2 \mathrm{~F})$ & 6 & - & AN/A \\
\hline $\begin{array}{l}\text { Caxton's Malory's La } \\
\text { Morte }\end{array}$ & $(1485)$ & $87(29 F)$ & $16(6 \mathrm{~F})$ & 7 & $74(2 F)$ & AN \\
\hline $\begin{array}{l}\text { Caxton, Four Sons of } \\
\text { Aymon } 1\end{array}$ & (c1489) & $34(6 \mathrm{~F})$ & $5(3 F)$ & $52(3 \mathrm{~F})$ & $45(4 \mathrm{~F})$ & $A$ \\
\hline $\begin{array}{l}\text { Caxton, Blanchardyn \& } \\
\text { Eglantine }\end{array}$ & $(\mathrm{c} 1489)$ & $14(5 \mathrm{~F})$ & $4(2 F)$ & $25(4 \mathrm{~F})$ & 9 & AN \\
\hline Caxton, Reynard the Fox & $(1489)$ & $31(1 \mathrm{~F})$ & - & 6 & $23(1 \mathrm{~F})$ & AN/ \\
\hline $\begin{array}{l}\text { Caxton, Doctrinal of } \\
\text { Sapience }\end{array}$ & (1489) & $36(7 F)$ & $12(3 \mathrm{~F})$ & $2(2 F)$ & 18 & AN \\
\hline Caxton, Eneydos & $(1490)$ & $15(2 \mathrm{~F})$ & $3(2 F)$ & 13 & $13(2 \mathrm{~F})$ & AN/ \\
\hline The Tretyse of Loue & $(1493)$ & $8(3 F)$ & 2 & $11(1 \mathrm{~F})$ & 17 & AN/ \\
\hline $\begin{array}{l}\text { Caxton, Four Sons of } \\
\text { Aymon } 2\end{array}$ & $(\mathrm{c} 1498)$ & $24(9 \mathrm{~F})$ & $4(4 \mathrm{~F})$ & $23(1 \mathrm{~F})$ & $32(5 F)$ & AN \\
\hline $\begin{array}{l}\text { Caxton, Prologues and } \\
\text { Epilogues } 1^{\text {st }}(15 \mathrm{c} .)\end{array}$ & $6(2 F)$ & 3 & - & 5 & $\mathrm{AN}$ & \\
\hline Caxton, Prologues $2^{\text {nd }}$ & $(15 \mathrm{c})$. & 1 & - & - & 1 & an \\
\hline Myracles of Oure Lady & (1496) & $9(4 \mathrm{~F})$ & - & 1 & 2 & $\mathrm{AN} /$ \\
\hline
\end{tabular}

Texts from London come almost exclusively from the $15^{\text {th }}$ century, with manuscripts containing Chaucer's prose (5 texts) representing the early part of the period, and Caxton's 15 texts from the latter half of the $15^{\text {th }}$ century. Chaucer's texts display a distribution of forms resembling that in Modern English. The form an and the conservative forms of MIN, THIN are found before $h$-words. The same pattern characterizes Wyclif's works and, with reference to the indefinite article only, Speculum Sacerdotale, where, curiously, the reduced forms of the possessive adjective prevail over the conservative ones. 
The 15 texts associated with Caxton show a lot of inconsistence as regards the distribution of $a n$ and $a$. Although representing the period of at least 75 years after Chaucer, Caxton's works, especially the later ones, show a lot of variation of both the article and the possessive adjective. Only Four Sons of Aymon in its two versions demonstrates the prevalence of the adjectival $n$-less forms, and to a lesser degree those of the $n$-less article before $h$-words. This unexpected variation testifies to a very unstable character of initial prevocalic $h$-in East Midland texts from the latter half of the $15^{\text {th }}$ century.

Worth noting is the non-etymological mute $h$ in an habundance (Caxton's Curial 14/r16).

\section{North (A/N, MI/N, THI/N before prevocalic $h$-)}

The distribution of the above words before prevocalic $h$-in the North is as follows (the border date text is treated as belonging to the $15^{\text {th }}$ century; for a full list of texts see the Appendix):

\section{(16) NORTH (17 texts) MS date AN MIN/THIN A MI/THI TYPE}

\begin{tabular}{|c|c|c|c|c|c|c|}
\hline Three ME Sermons & $(\mathrm{c} 1400)$ & 13 & 10 & - & - & AN \\
\hline Don Jon Gaytryge's Sermon & (c1440) & - & - & 1 & - & $\mathrm{a}$ \\
\hline $\begin{array}{l}\text { The Abbey of the Holy } \\
\text { Ghost }\end{array}$ & $(1400+)$ & - & 4 & 1 & 1 & $\mathrm{a}$ \\
\hline Alphabet of Tales 2 & $(1400+)$ & - & - & $76(8 \mathrm{~F})$ & 22 & A \\
\hline Hilton, Angel's Song & $(1400+)$ & - & - & 1 & - & $\mathrm{a}$ \\
\hline $\begin{array}{l}\text { Methodius, Bygyn. of the } \\
\text { World }\end{array}$ & $(1400+)$ & - & 1 & 6 & - & A \\
\hline Fistula in ano & $(\mathrm{c} 1425)$ & 4 & - & 4 & 2 & an/a \\
\hline English Conquest of Ireland & $(\mathrm{c} 1425)$ & $18(1 \mathrm{~F})$ & - & - & - & AN \\
\hline Alphabet of Tales 1 & $(1450+)$ & - & - & $98(6 \mathrm{~F})$ & $39(1 \mathrm{~F})$ & A \\
\hline Liber de Diversis Medicinis & $(\mathrm{c} 1440)$ & $13(3 \mathrm{~F})$ & $7(1 \mathrm{~F})$ & 56 & 9 & AN/A \\
\hline Mirror of St. Edmund & (c1440) & $1(1 \mathrm{~F})$ & 1 & 5 & 20 & an/A \\
\hline R. Rolle \& Followers 2a & (a1450) & 18 & 66 & 4 & 28 & AN/a \\
\hline R. Rolle \& Followers $2 b$ & (a1450) & $13(6 \mathrm{~F})$ & 32 & 2 & 14 & AN/a \\
\hline $\begin{array}{l}\text { R. Rolle, Yorks. Writers } \\
\text { rolhor }\end{array}$ & (a1450) & 10 & 92 & 23 & $148(1 \mathrm{~F})$ & AN/A \\
\hline $\begin{array}{l}\text { R. Rolle, Yorks. Writers } \\
\text { rolplus }\end{array}$ & (a1450) & 10 & 90 & 22 & $147(1 \mathrm{~F})$ & AN/A \\
\hline
\end{tabular}




$\begin{array}{lllllll}\begin{array}{l}\text { Craft of Dying } \\ \text { (Lowl. Scots) }\end{array} & \text { (c1475) } & 6 & - & - & - & \text { AN } \\ \begin{array}{l}\text { Wisdom of Solomon } \\ \text { (Lowl. Sc.) }\end{array} & (1475+) & - & - & - & 5 & \text { (a) }\end{array}$

The texts from the North in the Innsbruck Corpus all come from the $15^{\text {th }}$ century. In the Northern version of Three Middle English Sermons (c. 1400), an is found before initial vowels, but it fails to appear before consonant letters other than $h$ (around 650 occurrences before other consonants, which means that initial $h$-was treated by its author as mute). An analogous pattern is characteristic of The English Conquest of Ireland where only an stands before $h$-words. On the other hand the $n$-less forms of the adjective and the article only stand before $h$ - in Alphabet of Tales 1 and 2, which makes it clear that these texts retained initial $h$-. Rolle's texts exhibit much variation as regards the distribution of the article and the adjective, with a slight prevalence of the reduced forms.

\section{Conclusions}

To summarize, some general statements can be formulated on the basis of the above examination of the Innsbruck Corpus of Middle English Prose data:

(a) In dialects, an early loss of initial prevocalic $h$ - in Middle English words of Germanic origin is evidenced in particular texts rather than in texts from the whole region, typical examples being Ancrene Riwle Nero (West Midland; c. 1225), Ancrene Riwle (Pepys, c. 1225), and Lavynham's A Lytil Tretys; a1400) (East Midland), Lollard Sermons (a1400; SWE Midland), Chaucer (London; c. 1400 and later), and Three ME Sermons (c. 1400; North). The retention of $h$ - is seen in both versions of the Alphabet of Tales.

(b) South Western and West Midland texts in the Corpus do not contain the article $a$ before $h$ - until c. 1450, which testifies to the strong position of an in its function.

(c) Luick's distribution of initial $h$-retention is to some extent confirmed by the results of the present study, although Corpus texts from the North offer evidence of the loss of $h$ - in texts such as Liber de Diversis Medicinis, Rolle's Yorkshire Writers, or Alphabet, mentioned earlier.

(d) The Corpus data indicate that the initial impulse of the rise of the indefinite article was the split of an into $a$ and $a n$. Another impulse was the loss of $-n$ in mine, thine etc., resulting in the rise of a set of possessive adjectives with a syntactic, not phonological, distribution. 
(e) There is ample evidence in the Corpus that the implementation of the contemporary distribution, i.e., $a$ before consonants and an before vowels, had a partly regional character, its first signs belonging to the $13^{\text {th }}$ century.

I believe that the topic is worth further investigation, perhaps basing on corpora more comprehensive and precise than the Innsbruck Corpus, of the shortcomings of which I am fully aware. Let me hope that the results of the present "pilot" study may be of some use for the future researchers in that field. 


\section{APPENDIX}

A list of texts from the Innsbruck Corpus consulted

For a full explanation of symbols see Manual of the Innsbruck Prose Corpus, 57-64.

South-Western

History of the Holy Rood-tree <N Oxford, Bodley 343> <M 1150+ (1150-1250)> O 1050+ (OE) SO (West Saxon)

Hali Meidenhad <N Oxford Bodley 34, 52v ff (1150-1250)> SO / SWO

Hali Meidenhad, Titus, <N BL Cotton Titus D 18f. 112v ff 1150-1250<D SO / SWO>

Old English Homilies, <N Trinity Coll. Cbr., MS. B. $14.52<\mathrm{M}$ a1225<O a1200<D SO >

Twelfth-Cent. Homilies, <N Oxford, Bodley 343><M 1150+(1150-1250)> SO > dialect

A Myrour to Lewde Men and Wymmen, <N BL Harley 45> early 15)> (c1400 William of Nassyngton?, SO/SWO (Gloucestershire

Dialogus inter militem et clericum, N BM Harley 1900>Trevisa, John > beginningof 15)> a1402 (MED)> SO (West Southern)

Methodius, The Bygynnyng of the World, <N BM Harley 1900> Trevisa, John (?) $>(1359-1420$ ? $)>0(1350-1420$ ? $)><$ D SO (West Southern)

\section{Kentish}

Twelfth-Cent. Homilies, Oxford, Vespasian D. XIV 1150-1250, KO

Kentish Sermons, in Old English Miscellany $<$ N Oxford Laud MS. 471 > $<\mathrm{M}$ $(1250-1350, \mathrm{KL}$

\section{West Midland}

Hali Meidhad, collation of diff. MSS. $>\langle$ M 1150-1250) $>$ WMO $>$

Sawles Warde, in Old English Homilies, <N Bodleian MS. 34> <(1150-1250)> WMO

Liflade and Passion of St. Julian, <N Bodleiana Oxford, 34<M 1150+)>(11501250> WMO>

Liflade and Passion of St. Julian, MS Royal, $<\mathrm{N}$ Bodleiana Oxford, Royal 34<M 1150, O 1150-1250> WMO

Seinte Marherete, Bodley, ed. Mack. 13><N Oxford Bodley $34<\mathrm{M} 1150+$ $(1150-1250)>\mathrm{O} 1200+(\mathrm{c} 1230$ (Wells) $)>$ WMO (Herefordshire?) $>$

Ancrene Riwle, MS Corpus Christi College Cbr. 402<M 1200+><O 1200 WMO 
Ancrene Riwle, MS Gonville/Caius College Cbr. 234, (c1225 MED) O 1200 (?a1200) WMO?

Ancrene Riwle, MS B.L. Cotton Nero A. XIV $<$ M 1200+ (c1225 MED) $><\mathrm{O}$ 1200, WMO?

Seinte Marherete, Royal, <N BL Royal 17 A. XXVII $><$ M c1225 $>$ D WMO (Herefordshire)

Life of St. Katherine, Royal MS, <N Royal MS. 17 A XXVII $><$ M 1200+ (1225) $><$ D WMO (Hereford / Gloucester)

Wohunge of Ure Lauerd, BL Cotton Titus B. 18 $\rangle\langle\mathrm{M}$ a1300 $\rangle\langle\mathrm{D}$ WMO ? $\rangle$

Three Middle English Sermons <N Chapter Library Worcester F. 10> (c1400)> (1st serm.) WMO;

Saint Nicholas, <N MS BL Egerton 876><M 1450> WMO? LondonO?>

Saint Bartholomew, ed. Hamer. <N MS BL Egerton 876><M 1450+ (c1450)> $<\mathrm{O} 1438>\mathrm{WMO}$ ? / London O?

Saint George, <N B.L. Egerton 876.> c1460><O 1438> D WMO? (London?)

South/West Midland/East Midland

Lollard Sermons <N BL Add. 41321; Bodl. Rawlinson C 751; John Rylands Libr.

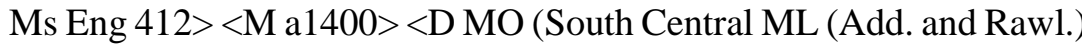

Three Kings of Cologne, $<\mathrm{N}$ Cbr. UL Ee iv, 32, 2 MSS $<\mathrm{M}$ c1450+ (end $14<\mathrm{O}$ ?c1400<D EMO/WMO (South Midlands) >

Three Kings of Cologne, Royal, $<\mathrm{N}$ BL Royal, $18 \mathrm{~A} x<\mathrm{M}$ c1450 (end $14 \mathrm{O}$ ?c1400><D EMO/WMO (South Midlands

Late Middle English Treatise on Horses, $<\mathrm{N}$ BL Sloane 2584, ff. 102-117v $<\mathrm{M}$ $1500<\mathrm{O}$ a1450 > <D SO / WMO / EMO (Berkshire/South Oxfordshire

The Art of Hunting, MS Porter (Phillipps MS 12086), Newhaven, Conn $<\mathrm{M}$ $1400+(\mathrm{c} 1445)>(1327)><\mathrm{SO} / \mathrm{WMO}$ (Worcester)

East Midland

The Peterborough Chronicle 1070-1154, <N Oxford, Bodley Laud Misc. 636> $1100-1200<\mathrm{D}$ EMO

Vices and Virtues, BM Stowe 240> (a1225)> < (c1200)> <D EMO (MED)

Ancrene Riwle <Magdalene College Cbr. MS Pepys 2498, c1225 MED<(?a1200, $\mathrm{EMO}$

Ancrene Riwle, <N MS Cotton Titus D. XVIII ff., M c1225 MED<O 1200 (?a1200, EMO?

Mandeville's Travels: Bodley Version, <N Oxford Bodl. E Musaeo 116>M $1350+\mathrm{EMO}>$

Pepysian Gospel Harmony <N Magd. Coll., Cbr., MS Pepys 2498> c1400)> $\mathrm{EMO} / \mathrm{SO}>$ 
Speculum Christiani, N BL Harley 6580 (c1450) > <O 1300+, EMO>

Capgraves's Abbreviation of Chronicles UL Cbr. Corpus Chr.Gg. 4.12(M)M c1462-1463 EMO

Capgrave's Lives of St. Augustine; BL Additional 36704<M (1440; EMO (Lynn, Norfolk)

Cely Letters 1472-1488, $<$ N Office, London, S.C.I 53/59> (1472-1488) EMO>

Cloud of Unknowing and the Book of Public Record Privy Counselling $<\mathrm{N}$ BL MS Harleian $674<$ (early 15)> (14/early 15, EMO (editor) > dialect

Deonise Hid Diuinite; <N BL Harl. 674, 993, 1022, 2373 et al.> M a1425> ?a1400> EMO

Middle English Translation of Macer Floribus de Viribus Herbarum, $<\mathrm{N}$ Stockholm Royal Library MS X 91> M 1450+> EMO (Oxford)>

Julian of Norwich's Revelations (Shorter Version $<\mathrm{N}$ BL Add. 37790, "Amherst Ms. " $>(\mathrm{c} 1420<\mathrm{c} 1413)>$ EMO $($ Norfolk

Lantern of Light, $<\mathrm{N}$ BL Harley 2324 $><\mathrm{M} 1400+(\mathrm{a} 1415$ (O (a1415) $><\mathrm{D}$ EMO (editor)

Lincoln Diocese Documents, 1450-1544<N Diocesan Registry at Lincoln Cathedral<M 1450+ (1450-1464) > <D EMO (Lincoln?) >

Works of John Metham: Physiognomy, <Oxford: All Souls 81 (1448/49 (editor<EMO Norfolk)

Nicholas Love, Mirror of the Blessed Life of Jesus Christ, $<$ N Cbr. UL Add. 6578 and 6686> (early 15) $>$ EML (Southern Northamptonshire, LALME) $>$

Misyn, The Fire of Love, <N Corpus Christi Coll. Oxf. MS. 236 > <M 1435)> EMO (editor) >

The English Register of Oseney Abbey, N Public Record Office, King's Remembrancer, Miscellaneous Books, no. 26> M (1460)> D EMO? (Oxfordshire)>

The Paston Letters, vol. 2-6, (1420-1500)> EMO>

De Pater Noster of Richard Ermyte. $<\mathrm{N}$ Westminster School Library MS. 3 $><\mathrm{M}$ $1400+\langle$ D EMO (Peterborough) $>$

Pecock, Reginald, The Donet, Oxford Bodley 916><M c1475><O c1445<D EMO

Pecock, Reginald, Follower to the Donet $<$ N BL Royal 17 D.ix > c1453-4 (editor, EMO (South East Midland / London)>

Lavynham, A Litil Tretys, <N BL Ms. Harley 211> (c1450)><O a1400<D EMO (Ipswich?)

Life of Adam and Eve, Wheatley MS, N BL Addit. MS 39574> (beginning $15<\mathrm{D}$ EMO>

Agnus Castus. A Middle English Herbal, N Stockholm Royal Libr. 90, M 1500+, EMO 


\section{London}

The Middle English Prose Complaint of Our Lady and Gospel of Nicodemus; $<\mathrm{N}$ Cambridge Magdalene Coll., Ms. Pepys 2498 (from Waltham Abbey, Essex $<\mathrm{M} 1350+(\mathrm{c} 1375$ ? $)><\mathrm{O} 1350+(2$ half $14<$ London $)$

Chaucer, The Tale of Melibeus, Hengwrt MS $><\mathrm{M} 1402 / 03><\mathrm{O} 1350+(\mathrm{c} 1387$ London $\mathrm{O}$

Chaucer, The Tale of Melibeus, <N Ellesmere MS $\langle\mathrm{M}$ 1410〉 (c1387) $\rangle$ LondonO>

Chaucer, The Persones Tale $\langle\mathrm{N}$ Hengwrt MS $\langle\mathrm{M}$ c1405 $\rangle$ (c1387) $\rangle\langle\mathrm{D}$ LondonO

Chaucer, The Persones Tale, <N Ellesmere MS > 〈M c1405> (c1387) $\rangle$ LondonO>

A Treatise on the Astrolabe, $<\mathrm{N}$ Univ. Libr. Dd. 3.53, $<\mathrm{M} 1400+(1391)>$ $\mathrm{K}$ cont.> London $\mathrm{O}>$

Book of the foundation of St. Bartholomew's BL Cotton Vespasian B ix $<\mathrm{M} 1400+$ (c1400)> London O?

The Revelations of Saint Birgitta; Libr. of Princeton University, Ms. in the Garrett Collection $><\mathrm{M} 1450+(\mathrm{a} 1475)>$ London O

Chaucer, Boethius, De Consolatione Philosophie, Cambridge Univ. Libr. Camb. Ii. 3. 21, with occasional use of other MSS> M ?a 1425+ (c1380< London $\mathrm{O}$

Caxton, Four Sons of Aymon, pt. I N unique Earl Spencer copy< (c1489)> (c1489)> LondonO?>

Caxton, Four Sons of Aymon; pt. II; <N unique Earl Spencer copy > (c1498)> c1498)> LondonO?>

Caxton, Blanchardyn and Eglantine, $\mathrm{N}$ Lord Spencer's unique imperfect copy $<\mathrm{M}$ 1450+ (c1489 (c1489)> LondonO?> dialect

The Curial made by Maystere Alain Charretier, tr. Caxton $<\mathrm{N}$ William Caxton 1484> (c1484)> O a1457> London?>

Dialogues in French and English $<\mathrm{N}$ Libr. of Ripon Cathedral, Caxton's printed text c1483>,London O?>

The Doctrinal of Sapience, pr. by Caxton; <N Henry E. Huntington Library, San Marino, California (base text 1489)> London O?>

Caxton's Eneydos; <N $>>$ main MS / print(1490)> D London O?>

The Book of the Knight of La Tour-Landry; tr. Caxton<N BL, Harley 1764> $(1483)><\mathrm{D}$ London?

Paris and Viene (Caxton); <N sig. c v > (1485, London O?>

Prologues and Epilogues of William Caxton, 1st ed. $<\mathrm{N}$ different prints $>$ $<\mathrm{M}$ various; $15 \mathrm{c}$. $>\mathrm{D}$ London $\mathrm{O}$

Prologues and Epilogues of William Caxton, 2nd ed. $<\mathrm{N}$ different prints $>$ $<\mathrm{M}$ various; $15 \mathrm{c}$. $>\mathrm{D}$ London $\mathrm{O}$

Caxton, Quattuor Sermones; ed.Blake $<\mathrm{N}$ print $>(\mathrm{c} 1483)><\mathrm{D}$ LondonO?> 
The Life of S. Thomas of Canterbury, in The Golden Legend ... by William Caxton $<\mathrm{N}$ print $<(\mathrm{c} 1470)>$ LondonO? (text normalized in spelling?) $>$

The History of Reynard the Fox, William Caxton 1481> (1481; 2nd ed. 1489)> LondonO>

Dicts and Saying of the Philosophers; <N Oxford Bodley 943><M1450<D LondonO (close to standard)

The Equatorie of the Planetis; Chaucer? $<\mathrm{N}$ Peterhouse MS 75.I $>$ (1418)> (c1392)> LondonO>

Three Lives from the Gilte Legende, $\langle\mathrm{N} \mathrm{x}\rangle\langle\mathrm{M} \mathrm{x}\rangle \mathrm{O} \mathrm{x}\rangle$ original date; $\langle\mathrm{D}$ LondonO

Malory's Le Morte Darthur, $<\mathrm{N}$ Caxton's edition, part $1<\mathrm{M} 1450+(1485)>$ $(1469-1470<\mathrm{D}$ London O>

The Myracles of Oure Lady, $<\mathrm{N}$ Wynkyn de Worde's edition $><\mathrm{M} 1496<\mathrm{D}$ LondonO (Chancery Standard) $>$

Speculum Sacerdotale, <N BL Add. 36791> (early 15) > ?c1425> LondonO>

The Tretyse of Loue, <N Pierpont Morgan Libr.> (1493 / 94)> <D LondonO?>

English Works of Wyclif, 1-2 $<\mathrm{N}$ Oxford, Bodley 788, and 7 others (see edition, p. VIf $<\mathrm{M}$ a1425><O c1480<D LondonO?>

North

Middle English Sermons <N Chapter Library Worcester F. 10> (c1400)> (2nd and 3rd Three sermon) $>\mathrm{NO}$

Dan Jon Gaytryge's Sermon, in Religious Pieces, pp. 1-15, <N Lincoln Cath. Libr. 91, Thornton MS.> M 1400+><O (c1440) > NO>

The Abbey of the Holy Ghost, N Lincoln Cath. Libr., Robert Thornton MS. 271276, M 1400+, <O 1350+, NO>

Alphabet of Tales 2, BM Addit. 25, 719> $<\mathrm{M} 1400+\rangle\langle\mathrm{O}$ a1294 $\rangle\langle\mathrm{NL}\rangle$

Hilton, Angels' Song, BL Add. 27592 $><\mathrm{M} \mathrm{1400+)>} \mathrm{NO}$ (West Yorkshire)

Methodius, The Bygynnyng of the World, N BM Additional 37949> Trevisa, John $(?)>\langle\mathrm{M} 1400+(1 / 15)\rangle\langle\mathrm{O} 1400+(1 / 15)>\mathrm{D} \mathrm{NO}$

Fistula in ano, London, BL Sloane 6> $<\mathrm{I}$ John Arderne, M c1425> NO (Rutland)

Alphabet of Tales $1<\mathrm{N}$ BL Addit. 25, 719> M 1450+, O a1294>, NL

Liber de Diversis Medicinis,N Lincoln Cath., Thornton Ms. A.5.2.> c1422c1454, NO Yorkshire

The Mirror of St. Edmund, in Religious Pieces in Prose and Verse, $<\mathrm{N}$ Lincoln Cath. Libr. Thornton Ms., lf. 197> main MS c1440)> O 1350+ (1350? [editor]) $><\mathrm{D}$ NO? (editor

Richard Rolle of Hampole ... and his Followers, vol. II, part 1 (2a), Yorkshire Writers, 1895), vol. II $><\mathrm{N}$ variable (MS. Cambr. UL Dd V. 64; Rawl. C 285; Arundel 507) M a1450> O a1349?> <NL> 
Richard Rolle of Hampole ... and his Followers, vol. II, part 1, (2b) Yorkshire Writers, <N various (MS. Cambr. Dd V. 64; Rawl. C 285; Arundel 507) $>\langle\mathrm{M}$ a1450 $>\langle\mathrm{O}$ ?a1349 $\rangle\langle\mathrm{D} \mathrm{NL}\rangle$

Richard Rolle of Hampole, Yorkshire Writers,rollhor $1<\mathrm{N}$ MS. Cambr. Dd V. 64 et al. (Rawl. C 285; Arundel 507) ><M a1450> O ?a1349><D NL>

Richard Rolle of Hampole, Yorkshire Writers (rolplus) $<\mathrm{M}$ a1450 $>\mathrm{O}$ ?a1349 $>$ $<\mathrm{D} \mathrm{NL}$

Craft of Dying, in Moral and Relig. Pieces, pp. 1-8; Lumby, J. Rawson, Cbr. Univ. Ms. KK. 1.5<M c1475> NO (Lowland Scots)

Ireland

The English Conquest of Ireland A.D. 1166-1185, Ms. Trinity Coll. Dublin, E. 3. 31> (c1425)> Irish?>

\section{REFERENCES}

Brunner, Karl. 1963. An outline of Middle English grammar [Translated by G. K. W. Johnston.]. Blackwell.

Ekwall, Eilert. 1975. A history of Modern English sounds and morphology. Blackwell.

Fischer, Olga \& Wim van der Wurff. 2006. Syntax. In Richard Hogg \& David Denison (eds.), A history of the English language, Cambridge University Press. 109-198. DOI: 10.1017/CBO9780511791154.004

Fisiak, Jacek. 1968. A short grammar of Middle English. Oxford University Press.

Hogg, Richard. 1992. A grammar of Old English. Vol. 1: Phonology. Wiley-Blackwell.

Jones, Charles. 1989. A history of English phonology. Longman.

Jordan, Richard. 1974 [1925]. Handbook of Middle English grammar (Translated and revised by Eugene J. Crook.). Mouton.

Lass, Roger. 1992. Phonology and morphology. In Norman Blake (ed.), The Cambridge history of the English language. Vol. 2. 1066-1476, Cambridge University Press. 23-155. DOI: 10.1017/CHOL9780521264754.003

Luick, Karl. 1940. Historische Grammatik der englischen Sprache. Vol. 2. Tauchnitz.

Lutz, Angelica.1991. Phonotaktisch gesteuerte Konsonantenveränderungen in der Geschichte des Englischen. Niemeyer.

Markus, Manfred (ed.). 2008. Innsbruck corpus of Middle English prose on CD-ROM. University of Innsbruck.

Milroy, James. 1983. On the sociolinguistic history of $/ \mathrm{h} /$-dropping in English. In Michael Davenport, Erik Hansen \& Hans Frede Nielsen (eds.), Current topics in English historical linguistics, Odense University Press. 37-54.

Milroy, James. 1992a. Middle English dialectology. In Norman Blake (ed.), The Cambridge history of the English language. Vol. 2. 1066-1476, Cambridge University Press. 156-206. DOI: $10.1017 /$ CHOL9780521264754.004

Milroy, James. 1992b. Linguistic variation and change. Blackwell. 
Minkova, Donka. 2003. Alliteration and sound change in Early English. Cambridge University Press. DOI: 10.1017/CBO9780511486968

Minkova, Donka. 2014. A historical phonology of English. Edinburgh University Press.

Scragg, D. G. 1970. Initial $H$ in Old English. Anglia 88. 165-196.

DOI: 10.1515/angl.1970.1970.88.165

Scragg, D. G. 1974. A history of English spelling. Manchester University Press.

Sommerer, Lotte. 2018. Article emergence in Old English: A constructionalist perspective. De Gruyter Mouton. DOI: 10.1515/9783110541052

Süsskand, Peter. 1935. Geschichte des unbestimmten Artikels im Alt- und Frühmittelenglischen. Niemeyer.

Wright, Joseph \& Elizabeth Mary Wright. 1928. An elementary Middle English grammar. Oxford University Press.

Wyld, Henry Cecil. 1936. A short history of English (3rd edn.). Murray. 